\title{
The Impact of Supervision from Head of School and Motivation of Educator in Working on the Performance of Educator
}

\author{
Fora Margeat Sumantri ${ }^{1 *}$, Bukman Lian ${ }^{2}$, Syaiful Eddy ${ }^{2}$ \\ ${ }^{1}$ SMP Negeri 3 Lempuing Jaya \\ ${ }^{2}$ University of PGRI Palembang \\ *Corresponding author. Email: sumantrifora@gmail.com
}

\begin{abstract}
This research aims to examine whether or not 1) the impact of supervision from head of school on the performance of educator; 2) the impact of educator's motivation in working on their performance; and 3) the impact of supervision from head of school and motivation of educator in working on the performance of educator. A quantitative method was used in this examination. The sample of this examination amounted to 70 educators of SD Negeri in the zoning area of 3 sub-districts of Lempuing Jaya. The research instrument in the form of a questionnaire consists of 5 options. The techniques in analyzing data analysis were 1) descriptive quantitative; also 2) multiple linear regression. The results stated that 1) there is a huge impact among the supervision from head of school on the performance of educator; 2) there is a huge impact among the educator's motivation in working on their performance, and 3) there is a huge impact jointly among the supervision from head of school and motivation of educator in working on the performance of educator.
\end{abstract}

Keywords: Supervision of the Principal, Teacher Work Motivation, Teacher Performance.

\section{INTRODUCTION}

According to the Law of the Republic of Indonesia Number 20 of 2003 concerning the National Education System, education is a cognizant and arranged exertion to understand the atmosphere and process of learning so students effectively build up their capability to have the strength in the spiritual aspect, discretion, character, knowledge, honorable ethics, also the essential abilities for themselves, community, country, and also nation. Education is one of the individual ways to foster personality following the values that exist in society and culture. Furthermore, education is the main tool that needs to be managed systematically and consistently based on various theories and practices that develop in life [1].

Education is the basic foundation for the progress of a nation by creating quality human resources. To produce quality resources can be seen from the performance of teachers who are the best in the success of something education. The headmaster must act as a manager, having the authority and policy in enhancing the education quality [2].

Its efforts in increasing human resources are an integrated effort with the increase in education [3]. The headmaster must be able to practice innovations, be able to bring his entire members and schools as an educational organization into a change of mind, also improving his vision and mission by utilizing his members' skills and abilities [4]. One of the principal duties is supervising, which aims to improve learning. If done well and intensively, it will affect the teacher's role in performing his or her daily tasks and duties, also leading to his improvement in performance at school. On the contrary, if the supervising has never been done, it can affect the educator's performance.

Supervision from the principal really supports the achievement of an effective and efficient learning process. The teachers will work in earnest if they have high motivation [5]. If they have a positive motivation, they will show interest, have attention, and want to participate in a task or an event. In keeping with that opinion, teachers who are still less successful in teaching must be taught because they are less motivated to teach and then resulting in decreased productivity or teacher performance. For that, the school's principals must motivate teachers to improve their performance. The leaders or principals must be able to be active and able to put themselves in a strategic position in the institutionalization. 
The success and effectiveness of a school principal in leadership can be achieved through rewarding, cooperating, and having knowledge of lower behavior [6] and [7]. A principal must have a management extension. Likewise, a teacher should have a high level of work ethic skill and passion, so they can allow all members to achieve a high performance.

Teachers who are competent in their fields will have a more positive impact on student development in understanding students [8]. The influence of work motivation can encourage teachers to work complacency because they are always consistent with their work. To achieve that, there must be a good cooperation between the head of the school and the teacher. Thus, proficient instructors are accepted to have the option to make understudies assume, perform, and respond imaginatively [9].

Based on the observations and interviews conducted by researchers on October 28-30, 2020 at 4 State Elementary Schools located in zoning 3, Lempuing Jaya district, concerning teachers who teach in his class under the leadership of the principal at this time, the state of the teacher is not following the hope that there are still some teachers who are late because of more leadership of personal management such as activities that routinely prefer personal care rather than principal activities as teachers in schools. The change in the pattern of work made by the headmaster was preceded by what is now making a difference to the performance of teachers both motivated and rewarded to teachers [10]. Besides, in performing its function as an educational teacher, the headmaster must be anticipating efforts to improve the quality of learning carried out by teachers.

In this case, the experience factor will greatly affect the professionalism of the principals. Their experiences as a teacher, being a deputy principal, or being a member of a community organization greatly influenced the ability of the principal in performing their work, as well as the training and stewarding that followed. However, the time for the head of school is based solely on the politics of the person until it happens. Thus, the professionalism of the school head is in doubt.

\section{METHODS}

This research used the quantitative research method. Researchers investigated problems by studying or reviewing research variables. A quantitative research with ex post facto design is an investigation directed to analyze occasions that have happened and afterward think back to discover the variables that could lead to such occasions [11].

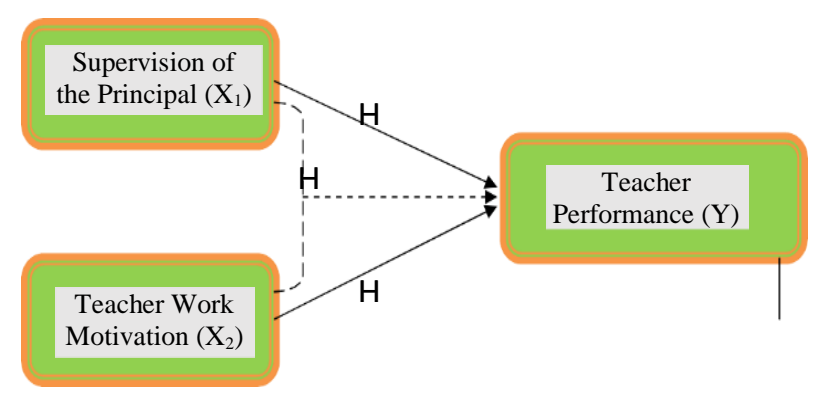

Figure 1. Research Design.

The research population is a speculation zone comprising of subjects or objects that possess some particular characteristics and qualities determined by specialists to be concentrated and afterward made inferences. It is not just individuals yet different articles and regular items. The research population is additionally the quantity of articles concentrated yet incorporates all attributes and qualities possessed by the subject or item concentrated but also in addition incorporates all qualities or properties. In this investigation, the populace was all teachers in SD Negeri cluster 3 with a total of 20 people. All data and information were not being processed and not everyone was researched but simply with a representative sample. Accordingly, tests taken from the populace should be genuinely delegate. To get a representative sample, sampling technique was required. Furthermore, because the study population is less than 100 respondents, then all populations should be used as samples [12].

Based on the description above, the research sample was the total population in the SD Negeri cluster 3, Lempuing Jaya District, totaling 70 respondents.

\section{RESULTS AND DISCUSSION}

\subsection{Testing the Effect of Principal Supervision on Performance of the Teacher.}

A relationshrip model of Supervision from the Principal to Performance of educator is stated in regression form of $\mathrm{Y}=17,174+0.430 \mathrm{X} 1$. In view of the variable importance test management of the head of school on the teachers' performance at SD Negeri cluster 3 Lempuing Jaya sub-district obtained a calculated $t$ value of $3,148>$ from the $t$ table value of 1,667 where the price of $t$ calculate more prominent than $\mathrm{t}$ table then Ho1 was acknowledged so that there was a huge impact between the supervision of the head of school on the teachers' performance at elementary schools in Lempuing Jaya sub-district. 
Table 1. The importance trial of the relapse condition

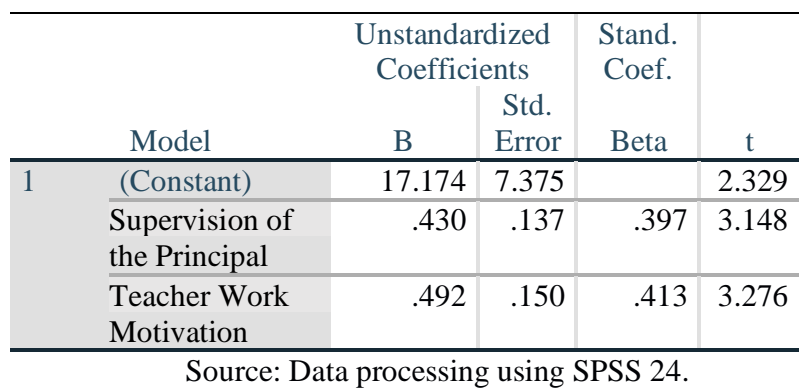

Table 2. Analysis of coefficient determination of the influence of principal supervision on teacher performance

\begin{tabular}{lc|r|r|r}
\multicolumn{5}{c}{ Model Summary } \\
\hline Model & R & $\begin{array}{c}\text { R } \\
\text { Square }\end{array}$ & $\begin{array}{c}\text { Adjusted } \\
\text { R Square }\end{array}$ & $\begin{array}{c}\text { Std. Error of } \\
\text { the Estimate }\end{array}$ \\
\hline 1 & $.719^{\mathrm{a}}$ & .517 & .510 & 3.538 \\
\hline \multicolumn{5}{r}{ Source: SPSS 24 data processing. }
\end{tabular}

As shown in the table 1 and 2, an adjusted R Square (Determinant coefficient) value is obtained by 0.510 which means that the impact of the variable of Principal Supervision (X1) on the variable of Teacher Performance $(\mathrm{Y})$ is $51.0 \%$.

\subsection{Testing the Impact of Educator Motivation on Their Performance}

The teacher's work motivation relationship model (X2) to their performance is presented as relapse $\mathrm{Y}=$ $17,174+0.492 \mathrm{X} 2$. The importance trial of the relapse condition is shown in the accompanying table 3 .

Table 3. Significance of the Teacher Motivation Impact on their Performance

\begin{tabular}{|c|c|c|c|c|}
\hline \multicolumn{5}{|c|}{ Coefficients $^{a}$} \\
\hline \multirow[b]{2}{*}{ Model } & \multicolumn{2}{|c|}{$\begin{array}{l}\text { Unstandardized } \\
\text { Coefficients }\end{array}$} & \multirow{2}{*}{$\begin{array}{c}\text { Standardized } \\
\text { Coefficients } \\
\text { Beta }\end{array}$} & \multirow[b]{2}{*}{$\mathrm{t}$} \\
\hline & $\mathrm{B}$ & $\begin{array}{l}\text { Std. } \\
\text { Error }\end{array}$ & & \\
\hline 1 (Constant) & 17.174 & 7.375 & & 2.329 \\
\hline $\begin{array}{l}\text { Supervision of } \\
\text { the Principal }\end{array}$ & .430 & .137 & .397 & 3.148 \\
\hline $\begin{array}{l}\text { Teacher Work } \\
\text { Motivation }\end{array}$ & .492 & .150 & .413 & 3.276 \\
\hline
\end{tabular}

In the view of test of the significance of teacher motivation variables (X2) to the performance at SD Negeri cluster 3, Lempuing Jaya sub-district obtained a calculated $t$ value of 3,276 > from $t$ table value of 1,667 where the price of $t$ calculate is more noteworthy than $t$ table then Ho 2 is acknowledged so that there is a huge impact between the work motivation or inspiration on the teacher performance.
Table 4. Analysis of determining the coefficient of the impact of motivation in working of educator on their performance

\begin{tabular}{lc|c|c|r}
\multicolumn{5}{c}{ Model Summary $^{\mathbf{b}}$} \\
\hline & & $\mathrm{R}$ & Adjusted & $\begin{array}{c}\text { Std. Error of } \\
\text { Model }\end{array}$ \\
& $\mathrm{R}$ & Square & R Square & the Estimate \\
\hline 1 & $.723^{\mathrm{a}}$ & .522 & .515 & 3.519 \\
\hline \multicolumn{4}{c}{ Source: Data processing using SPSS 24. }
\end{tabular}

From the output above, changed $\mathrm{R}$ Square (Determinant coefficient) estimation of 0.515 implies the impact of the Teachers Motivation in working variable (X2) on the Performance of Teacher variable (Y) of 51.5\%. It tends to be reasoned that the educator's work inspiration can fundamentally affect their exhibition. The aftereffect of the examination of educator's work inspiration on educator training execution is $51.5 \%$. The calculation outcome proves that the motivation in working can also affect the teachers' performance at SD Negeri cluster 3 Lempuing Jaya subdistrict.

\subsection{Testing the Head of School Supervision and Educators Motivation Impact on the Performance of Educator}

There is an influence joint of the head of school supervision and educators motivation impact on the performance of educator in several public elementary schools in Lempuing Jaya district. Based on multiple regression test results, then obtained the consistent estimation of the relapse condition (a) of 17,174 and the coefficient value of the free variable (b1) of 0.430 and the value (b2) of 0.492 , then the point the relapse condition: $\mathrm{Y}=\mathrm{a}+\mathrm{b} 1 \mathrm{X} 1+\mathrm{b} 2 \mathrm{X} 2 \mathrm{Y}=17,174+0.430 \mathrm{X} 1$ $+0.492 \mathrm{X} 2$. It means that the teacher's exhibition has improved positively.

To discover the accuracy of hypothesis theory testing, the simulation test is done by utilizing the $\mathrm{F}$ test to find out the impact of the principal supervision and teacher's motivation in working variables on teacher performance. The basis of decision making in test $\mathrm{F}$ is described below.

a. If the probability (significant) $<0.005$, it means that Ho 3 is rejected,

b. If the probability (significant) $>0.005$, it means that Ho 3 is accepted.

At that point for test $\mathrm{F}$, the test standards are:

a. Ha 3 is received if $\mathrm{F}$ calculates $>\mathrm{F}$ table,

b. Ho 3 is accepted if $\mathrm{F}$ calculates $\leqslant \mathrm{F}$ table.

The various relapse investigations results can be found in the accompanying table 5 . 
Table 5. Significance of the Relapse Investigations

\begin{tabular}{llr|r|r|r|r}
\multicolumn{8}{c}{ ANOVA $^{\mathbf{a}}$} \\
\hline & Sum of & \multicolumn{1}{c}{ Mean } & & \\
& Model & Squares & df & Square & \multicolumn{1}{c}{ F } & Sig. \\
\hline 1 & Regression & 1028.277 & 2 & 514.138 & 46.962 & $.000^{\mathrm{b}}$ \\
\cline { 2 - 7 } & Residual & 733.509 & 67 & 10.948 & & \\
\cline { 2 - 7 } & Total & 1761.786 & 69 & & & \\
\hline \multicolumn{7}{c}{ Source: Data processing using SPSS 24. }
\end{tabular}

From the ANOVA test above, obtained F calculates 46,962 with a significant rate of $0.000<$ probability esteem $\alpha 0.05$ while $\mathrm{F}$ table relates to the degree of significance of 0.05 (3.13) of 3.13 so that $F$ calculates > F table (46.962 > 3.13) to Ho 3 in decline, this means that there is a huge impact among the supervision from the head of school and educators' motivation in working on the teacher performance in SDN cluster 3 Lempuing Jaya sub-district.

Table 6. Analysis of coefficient determination of the head of school supervision influence (X1) and teacher motivation in working (X2) on performance of the teacher $(\mathrm{Y})$

\begin{tabular}{|c|c|c}
\multicolumn{3}{c}{ Model Summary } \\
\hline $\begin{array}{c}\mathrm{R} \\
\text { Square }\end{array}$ & $\begin{array}{c}\text { Adjusted R } \\
\text { Square }\end{array}$ & $\begin{array}{c}\text { Std. Error of the } \\
\text { Estimate }\end{array}$ \\
\hline .584 & .571 & 3.30876 \\
\hline \multicolumn{3}{|c}{ Source: Data processing using SPSS 24.}
\end{tabular}

From the output above, adjusted $\mathrm{R}$ Square (Determinant coefficient) estimation of 0.571 which implies the impact of the supervision from head of school variable (X1) and educators' motivation in working (X2) of Performance of educator variable (Y) of $57.1 \%$.

\section{CONCLUSION}

In summary, it is realized that the principals' management and inspiration working for instructor execution is 46,962 with a significance of 0.000 , so it very well may be reasoned that the oversight of the head of school and the educator's work inspiration can simultaneously affect the instructor's instructing execution. A result of calculation obtained a value of $57.10 \%$. The figure proves that the high level of supervision of the principal and the motivation of the educator's work impacts the presentation of the instructors of some State Elementary School cluster 3 Lempuing Jaya sub-district. The higher the supervision of the head of school and higher the educator's work motivation, this will be precisely proportional to the teacher's performance.

\section{ACKNOWLEDGMENTS}

The researchers give thanks to the Principals of State Elementary Schools located in the zoning of 3 Lempuing Jaya sub-districts, rector of PGRI Palembang University, Director of Postgraduate Program of PGRI
Palembang University, Education Management Study Program of PGRI Palembang University, and Supervisors 1 and 2 who have provided support for us to do this extraordinary thing. I would also like to thank my compatriots in Education Management who helped a lot in completing this scientific work in a limited period of time.

\section{REFERENCES}

[1] Rusmaini, R. (2014). Pengaruh Kondisi Sosial Ekonomi Orang Tua Terhadap Prestasi Akademik Mahasiswa Pada Program Studi Pendidikan Ekonomi STKIP PGRI SUMBAR (Studi Kasus Pada Mahasiswa yang Berasal dari Kabupaten Pasisir Selatan) (Doctoral dissertation, STKIP PGRI Sumatera Barat).

[2] Balfanz, R., Bridgeland, J. M., Moore, L. A., \& Fox, J. H. (2010). Building a Grad Nation: Progress and Challenge in Ending the High School Dropout Epidemic. Civic Enterprises.

[3] Yuliandri, J., \& Kristiawan, M. (2017). Peran Kepemimpinan Kepala Sekolah Terhadap Peningkatan Kinerja Guru. Jurnal Dosen Universitas PGRI Palembang.

[4] Andriani, S., Kesumawati, N., \& Kristiawan, M. (2018). The influence of the transformational leadership and work motivation on teachers performance. International Journal of Scientific \& Technology Research, 7(7), 19-29.

[5] Mulyasa, E. (2004). Manajemen berbasis sekolah: konsep, strategi dan implementasi. Remaja Rosdakarya: Bandung.

[6] Tobari. ,Kristiawan, M., \& Asvio, N. (2018). The Strategy of Headmaster on Upgrading Educational Quality InAsean Economic Community (AEC) Era. International Journal of Scientific \& Technology Research, 7(4).

[7] Hallinger, P., \& Murphy, J. F. (1986). The social context of effective schools. American journal of education, 94(3), 328-355.

[8] Satianingsih, R., Budiyono, S. C., \& Subandowo, M. (2020). Character Education in Multicultural Society: Case in Indonesia. International Journal of Multicultural and Multireligious Understanding, 7(4), 337-344.

[9] Evans, L. (1998). Teacher morale, job satisfaction and motivation. Sage.

[10] Ladyong, B. L. (2014). Organizational climate and teachers' work motivation: a case study of selected schools in Prachinburi, Thailand. Scholarly Journal of Education, 3(5), 52-57.

[11] Sugiyono. (2015). Metode Penelitian Pendidikan Pendekatan Kuantitatif, Kualitatif, dan R\&D. Bandung: Alfabeta.

[12] Sugiyono (2013) Metode penelitian kuantitatif, kualitatif dan R\&D, Bandung: Alfabeta. 